\title{
Particle processing mechanisms in the archaic, peri-hydrothermal vent bivalve Bathypecten vulcani, inferred from cilia and mucocyte distributions on the gill
}

\author{
Peter G. Beninger ${ }^{1, *}$, Suzanne C. Dufour ${ }^{2}$, Priscilla Decottignies ${ }^{1}$, Marcel Le Pennec ${ }^{3}$ \\ ${ }^{1}$ Isomer, Faculté des Sciences, Université de Nantes, 44322 Nantes Cédex 3, France \\ ${ }^{2}$ Marine Biology Research Division, Scripps Institution of Oceanography, 9500 Gilman Drive, La Jolla, California 92093-0202, USA \\ ${ }^{3}$ Institut Universitaire Européen de la Mer, Université de Bretagne Occidentale, Site technopôle Brest Iroise, \\ 29280 Plouzané, France
}

\begin{abstract}
The autobranch bivalve Bathypecten vulcani is a peri-hydrothermal vent 'living fossil'; as such, it is of particular interest both with respect to its trophic strategy and with respect to its particle processing mechanisms. These aspects are investigated through a study of the gill using scanning electron microscopy and mucocyte mapping. B. vulcani possesses a flat, homorhabdic gill, which lacks the morphological specializations associated with endosymbiont presence. Abfrontal and latero-frontal cilia, frontal tract differentiation, organic inter- or intrafilamentar junctions, an ascending lamella on the external demibranchs, and ventral particle grooves are all absent. The lack of latero-frontal cilia in this homorhabdic gill points to direct particle capture on the frontal tracts, a novel mechanism in adult bivalves. The abundant mucus-particle masses on the ventralmost frontal surfaces, which first come in contact with incoming water currents, together with an extremely high density of acid (AM) and acid-dominant (ADM) mucopolysaccharide-secreting mucocytes, suggest that particle capture is initially effected in this zone. The presence of antero-posteriorly oriented mucus cords in the gill arch indicate that transport on the gill is first dorsal, then anteriorward to the buccal region. An increasing postero-anterior gradient in mucocyte numbers and volumes suggests that transfer to the labial palps occurs via an exposed mucus bridge. These findings are the first substantiated representations of primitive autobranch particle processing, prior to the evolution of ventral particle grooves, latero-frontal cilia, or the heterorhabdic condition. It thus serves as a starting point for the understanding of the evolution of particle processing mechanisms in the basal pectinid condition, as well as in contemporary autobranch bivalves.
\end{abstract}

KEY WORDS: Gill · Bivalve $\cdot$ Hydrothermal $\cdot$ Feeding

Resale or republication not permitted without written consent of the publisher

\section{INTRODUCTION}

The adaptations and physiology of hydrothermal vent organisms have been the objects of considerable research over the past 2 decades (see Tunnicliffe 1991, Le Pennec et al. 1995, Le Pennec \& Beninger 2000, Van Dover 2000 for recent reviews and references). In particular, the conspicuous bivalve fauna surrounding hydrothermal vents has been intensively studied, and

*Email: peter.beninger@isomer.univ-nantes.fr has come to symbolize metazoan life in vent environments (Childress et al. 1987).

A range of trophic strategies is observed in hydrothermal vent bivalves, from complete reliance on endosymbionts to mixotrophy, in which both endosymbiotic and suspension-feeding strategies are used (Page et al. 1991, Le Pennec et al. 1995). The gills of mixotrophic vent bivalves can capture detritus and particles suspended in vent waters, including phytoplankton trans-

(c) Inter-Research $2003 \cdot$ www.int-res.com 
ported along advective currents around smokers (Enright et al. 1981, Le Pennec et al. in press).

Of the documented species of bivalves at hydrothermal vents, the small $(<10 \mathrm{~mm})$ pectinacean Bathypecten vulcani may be the only one without chemosymbionts. While the original report (Le Pennec et al. 1988) of few bacteria in the gill filaments of this species requires unambiguous confirmation, the uncharacteristically small-diameter filaments argue against a normal endosymbiont presence. The observation of abundant particles on the gills and in the stomach of B. vulcani (Le Pennec et al. in press) indicates that suspension-feeding provides an important part of its trophic requirements. No determinations of stable isotope ratios or enzyme activities have been made on this species to date.

Based on shell characters only, Bathypecten vulcani was initially placed in the family Pectinidae (ScheinFatton 1985) (Superfamily Pectinacea), later considered to be an archaic species preceding the divergence of the families Propeamussiidae and Pectinidae (ScheinFatton 1988), and finally to belong to a subfamily of the Pectinidae (Schein 1989). In these studies, B. vulcani is consistently considered a relict species, or 'living fossil', basal to the pectinid and propeamussid forms. Initial research has shown that the gill of $B$. vulcani is flat and homorhabdic (i.e. has only 1 type of filament; heterorhabdic gills have 2 types) and lacks laterofrontal cilia (Le Pennec et al. 1988). Such an assemblage of gill characteristics is unknown among adults of the well-studied pectinids, and indeed among the Bivalvia as a whole; it is therefore probable that feeding processes are also unique in this species. Due to the small size and pressurized habitat of this species, direct observation of gill function using videoendoscopy (e.g. Ward et al. 1991, 1993, Beninger et al. 1992) has not been possible. However, the distributions of cilia and mucocytes on the feeding organs provide considerable information which may be used to infer how particles are captured and treated (Beninger \& Dufour 1996, Beninger \& St-Jean 1997a,b). This approach has been used in the present study of the gill organization and particle processing mechanisms of B. vulcani.

\section{MATERIALS AND METHODS}

Sampling and fixation. Specimens of Bathypecten vulcani were collected in February 1996 and May 2000, during vent cruises to 9 and $13^{\circ} \mathrm{N}$ along the East Pacific Rise. They were either brought back as bycatch along with other vent fauna, such as tubeworms and mussels, or specifically collected after identification at 2 sites: Tubeworm Pillar (94 $49.6^{\prime} \mathrm{N}, 104^{\circ} 17.38^{\prime} \mathrm{W}$; depth: 2540 m) and Marker 141 (949.8' N, 104 17.4' $\mathrm{W}^{\prime}$; depth: $\sim 2530 \mathrm{~m}$ ) along the transect established by Shank et al. (1998). When seen, the bivalves were located at the periphery of active smokers or vent fields, coexisting with limpets and serpulid polychaetes.

Upon arrival on board, the 4 specimens collected in February 1996 were fixed in buffered seawater with $10 \%$ formalin and preserved in $100 \%$ ethanol. Two specimens collected in May 2000 were placed whole in a solution of $2.5 \%$ glutaraldehyde in a slightly hyperosmotic (1058 mOsm), $0.1 \mathrm{M}$ sodium cacodylate buffer (Beninger et al. 1995a), and 5 specimens were fixed in aqueous Bouin's fixative (Martoja \& Martoja 1967).

General anatomy. Three specimens from 1996 were studied under a dissecting microscope in order to ascertain the general anatomical organization (such information has been lacking to date for this species).

Scanning electron microscopy (SEM). Entire specimens (1 from 1996 and 2, glutaraldehyde-fixed, from 2000) were prepared for SEM observation and photography by removing the right valve and mantle and dehydrating, critical-point drying, and sputter-coating the left valve and tissues. In addition, gill portions (anterior or posterior half of inner and outer demibranchs) of 2 specimens from 1996 were similarly prepared and observed.

Histological and whole mount staining. The specimens placed in Bouin's fixative (shell-less, the acetic acid in the fixative having dissolved the calcium carbonate of the extremely thin shell) were either sectioned or stained as whole mounts. In the first case, 1 whole specimen was embedded in paraffin, and $7 \mu \mathrm{m}$ thick transverse sections were stained with periodic acid-Schiff-Alcian Blue (PAS-AB; Beninger et al. 1993, Beninger \& St-Jean 1997a,b), with modified staining times: $25 \mathrm{~min}$ in Alcian Blue, $2 \mathrm{~min}$ in periodic acid, and $15 \mathrm{~s}$ in Schiff's reagent. Additional sections of the same individual were stained with modified Masson's trichrome (Beninger et al. 1995b), with the following optimal staining times: trioxyhematein, 1 min $30 \mathrm{~s}$; $0.5 \%$ Acid Fuchsin, $30 \mathrm{~s}$; and $\%$ Fast Green, $3 \mathrm{~min}$. In the second case, 4 specimens were stained as whole mounts. Entire animals were placed in staining capsules and stained with PAS-AB as in Beninger et al. (1993), optimal staining times being 5 min in Alcian Blue 8GX, 2 min in periodic acid, and $10 \mathrm{~s}$ in Schiff's Reagent. From the stained specimens, the demibranchs were removed and the ascending and descending lamellae were separated. The latter were divided into 3 portions along the antero-posterior axis, and each portion was mounted on a slide in aqueous medium (Gel Mount, Biomeda). Standard color equivalents were assigned using the Pantone ${ }^{\mathrm{TM}} 2001$ universal color guide (Beninger et al. 1993). 
Mucocyte counts. The whole mount preparations of the anterior, median and posterior gill regions were used for mucocyte counts, following the procedure of Beninger et al. (1993). From these preparations, 3 counting zones were determined along the dorso-ventral axis: dorsal, median, and ventral. Counts of each type of mucocyte along a length of $370 \mu \mathrm{m}$ (the diameter of the optical field at $200 \times$ ) were made on 10 filaments chosen at random in each different zone, and average mucocyte densities per zone were determined. To allow for comparisons with previously published data, the results are presented as mucocyte number along a filament length of $100 \mu \mathrm{m}$. Non-parametric ANOVAs (KruskalWallis, 1-factor analysis on ranks), and Dunn's multiple comparisons test were used to determine whether mucocyte numbers differed significantly among the antero-posterior and dorso-ventral axes.

Examination of the whole mounts showed the presence of 2 different mucocyte types: ellipsoid-shaped, acid-dominant mucopolysaccharide-secreting mucocytes (ADM), and spherical, acid mucopolysaccharidesecreting mucocytes $\left(\mathrm{AM}_{i}\right.$ see Beninger \& St-Jean 1997a for functional correlates of mucocyte types). To take into account the size difference between these 2 mucocyte types, a total mucocyte volume per $100 \mu \mathrm{m}$ filament length was determined for each type and in each counting zone; this gives a better idea of each type's contribution to the mucus, and its consequent viscosity, at different sites on the gill (Dufour \& Beninger 2001). The mean maximal length $(l)$ and width $(w)$, or radius $(r)$ was determined from 30 mucocytes of each type, and the mean volume $(\mathrm{V})$ was calculated from those values, by approximating mucocytes to either spheres $\left(v=4 / 3 \pi r^{3}\right)$ or ellipsoids $\left(v=4 / 3 \pi l w^{2}\right.$, where $l$ is the length of the major axis and $w$ is the length of the minor axis). The mean number of mucocytes of a given type per $100 \mu \mathrm{m}$ of filament length was then multiplied by the corresponding mean mucocyte volume to obtain the total mucocyte volume.

\section{RESULTS}

\section{Bathypecten vulcani anatomy}

Visible features of the gross anatomy of Bathypecten vulcani included: a mantle with a row of tentacles and velum, a small adductor muscle, gonads, a digestive gland and short digestive tract, a foot with byssal threads, labial palps, and a gill with a straight axis. The position and anatomical relationships of these features are shown in Fig. 1. The pericardium and heart were not observed, as they are normally thin, transparent, and collapsed in fixed specimens (Beninger \& Le Pennec 1991).

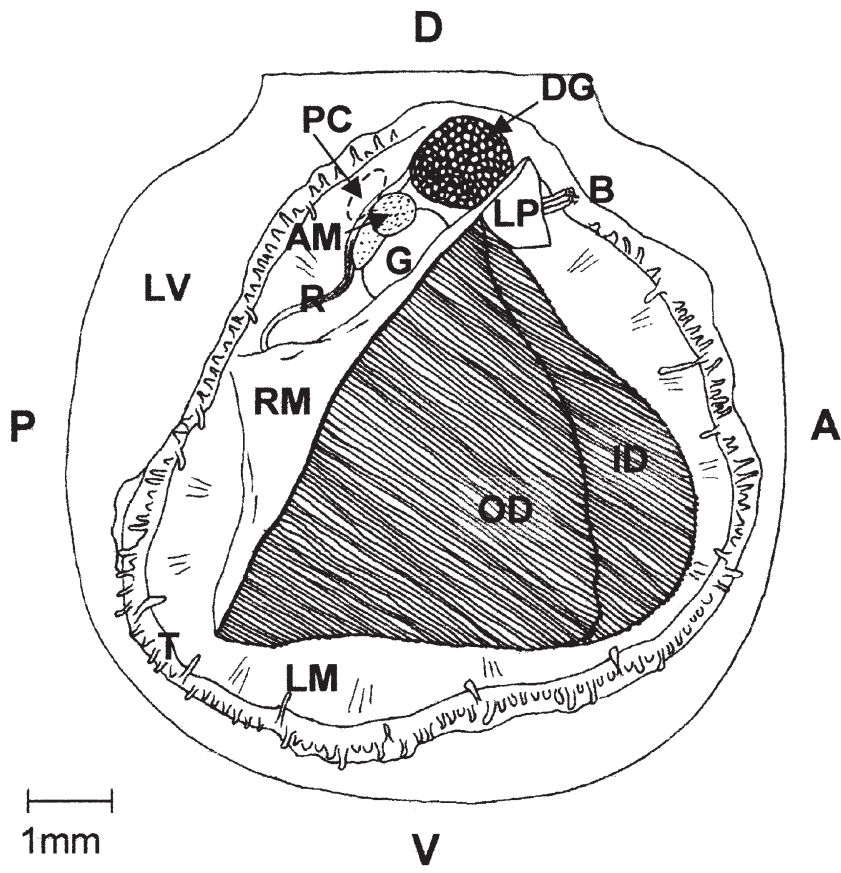

Fig. 1. Bathypecten vulcani. General anatomy, drawn from preserved specimens. The foot cannot be seen on this diagram as it is covered by the labial palp. AM, adductor muscle; B, byssus; DG, digestive gland; $G$, gonad; ID, inner demibranch of right gill; LP, right labial palp; LM, left mantle lobe; $\mathrm{LV}$, left valve; OD, outer demibranch of right gill; $\mathrm{PC}$, putative location of pericardium; $\mathrm{R}_{\text {, rectum; }} \mathrm{RM}$, reflected right mantle lobe; $\mathrm{T}$, tentacles on the velum. Orientations (A, anterior; $\mathrm{D}$, dorsal; $\mathrm{P}$, posterior; $\mathrm{V}$, ventral margins) are indicated with respect to shell rather than to body structures (see Beninger \& Le Pennec 1991)

\section{Gill structure}

Bathypecten vulcani gills are homorhabdic and flat, consisting of approximately 50 filaments per demibranch. When viewed transversely, the gills do not present the typical $\mathrm{W}$ shape of most bivalve gills; rather, they are $\mathrm{N}$-shaped, having a reflected inner demibranch and a non-reflected outer demibranch (Fig. 2). The ascending filaments of the inner demibranch are approximately $2 / 3$ the length of the descending filaments. The inner demibranchs of both gills are joined together by cilia at the paddle-shaped extremities of the ascending filaments (Fig. 2a), and the similarly paddle-shaped extremities of the descending filaments of the outer demibranchs are fixed to the mantle by ciliary junctions (Fig. 2c).

Upon dissection, the filaments were tangled and disjoined, indicative of a low degree of inter-filamentar cohesion; indeed, SEM examination revealed that the intact portions presented widely spaced filaments. The inter-filamentary junctions were limited to the ventral bend of the inner demibranchs (Fig. 2b). 


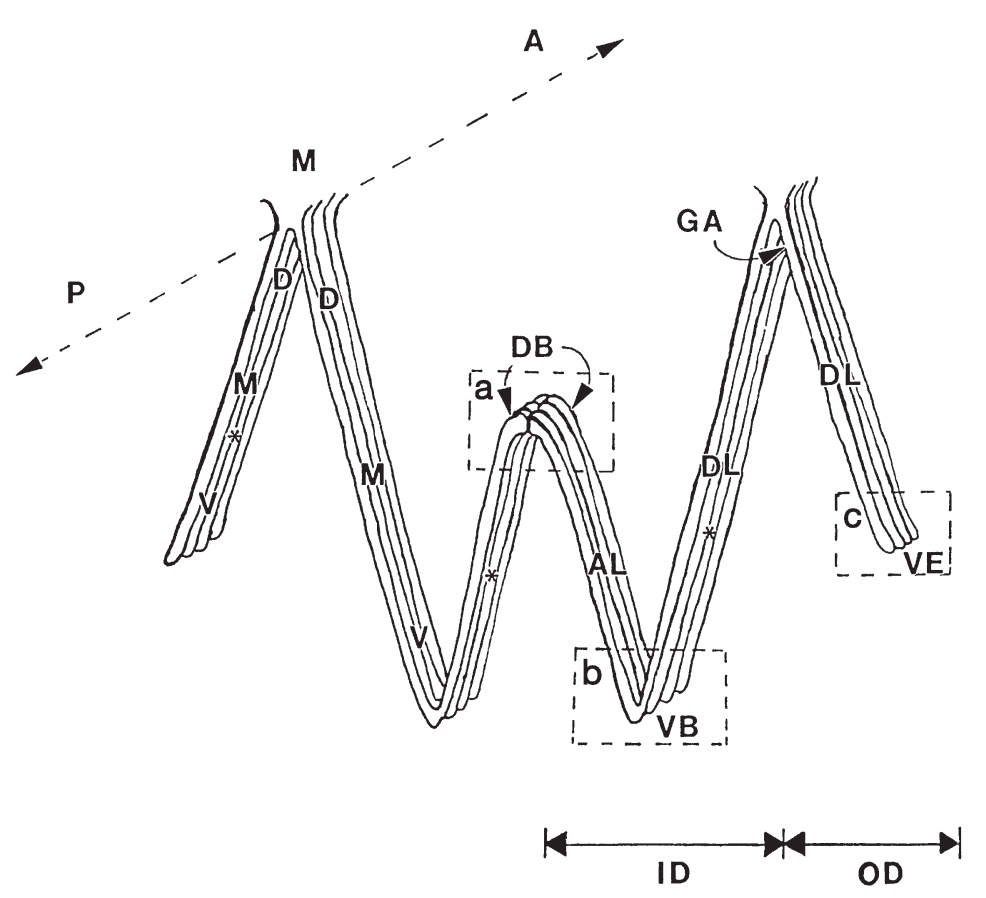

a
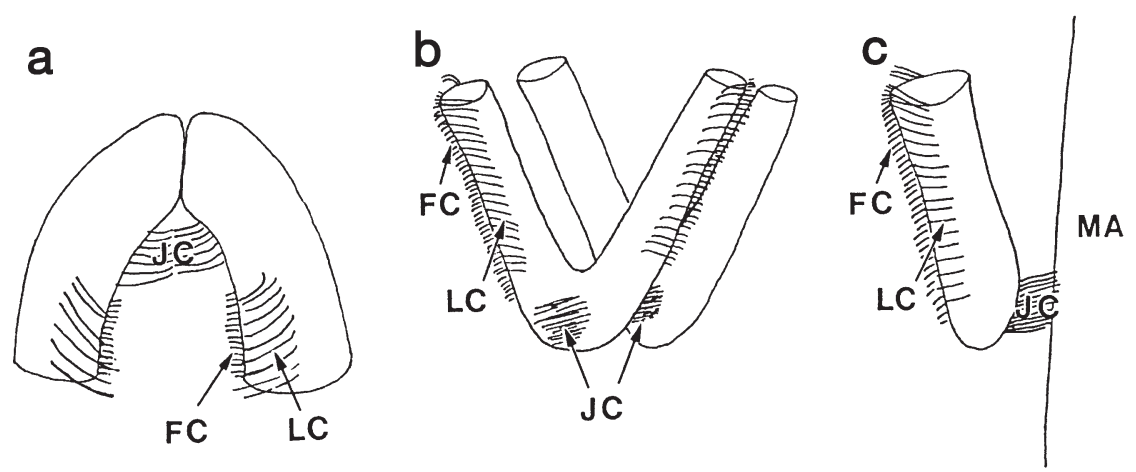

Fig. 2. Bathypecten vulcani. Schematic drawing of the gill, indicating the 3 anteroposterior counting regions (A: anterior, M: middle, P: posterior) and the 3 dorsoventral counting zones (D: dorsal, $\mathrm{M}$ : middle, V: ventral). The visible frontal surfaces of the filaments are indicated by asterisks. The areas (a), (b) and (c) are enlarged to show the position of J-cilia. AL, ascending lamella; DB, dorsal bend; DL, descending lamella; GA, gill arch; ID, inner demibranch; OD, outer demibranch; VB, ventral bend; VE, ventral extremity. (a) Ciliary junctions between ascending filaments of the inner demibranchs at the dorsal bend. FC, frontal cilia; JC, J-cilia; LC, lateral cilia. (b) Inter-filamentar junctions at the ventral bend of the inner demibranchs. (c) Junctions between the ventral extremity of the descending filaments of the outer demibranchs and the mantle. MA, mantle

\section{Gill ciliation}

SEM observations revealed that ciliation patterns along a filament are the same in the anterior, median and posterior gill regions, as well as on inner and outer demibranchs. Each filament possessed 3 rows of cilia: a row of $6 \mu \mathrm{m}$ long frontal cilia, and 2 rows of $20 \mu \mathrm{m}$ long lateral cilia, 1 on either side of the filament (Figs. 2a-c \& 3a). The latter were long enough to reach and partly cover the frontal cilia (Figs. 3b,d \& 5g). No laterofrontal or abfrontal cilia or cirri were found in any of the specimens observed. Mucus and particles were seen among or atop the frontal cilia (Fig. 3c-e), as well as in the densely ciliated dorsal arch (Fig. 3f,g), the ventral bend of the inner demibranchs (Fig. 4a), and the ventral extremity of the outer demibranchs (Fig. 4c). Of these sites, only the dorsal arch contained well-defined mucus cords (Fig. 3f,g).

The frontal surface of the ventral bend of the inner demibranchs was covered with $6 \mu \mathrm{m}$ long cilia. On the lateral surfaces of the ventral bend, longer $(20 \mu \mathrm{m}), \mathrm{J}$-tipped cilia (Fig. 4e) formed junctions between filaments (Fig. 4b). Similar J-cilia were found on the abfrontal surface of the paddle-shaped extremities of the outer descending filaments (Fig. 4d), as well as at the point of attachment of the inner demibranchs to one another (Fig. 4f). Inter-lamellar junctions were absent throughout the gill.

Fig. 3. Bathypecten vulcani. Scanning electron micrographs of gill filaments. (a) Lateral view of a gill filament, showing absence of latero-frontal cilia. AS, abfrontal surface; FC, frontal cilia; LC, lateral cilia; LFS, latero-frontal surface. (b) Lateral view of a gill filament, with lateral cilia extended and reaching the frontal surface. (c) Lateral view of gill filament, with mucus-particle masses (P) on the frontal surface of the filament. Frontal cilia of adjacent filaments are visible above and below the filament. (d) Frontal view of 3 gill filaments, with dehydrated mucus balls (M), probably the vestiges of mucus rafts, visible among the frontal cilia. (e) Higher magnification of the frontal surface, showing dehydrated mucus balls along the frontal cilia. (f) View of frontal surface of gill arch (GA), in which are seen mucus-particle masses and a dehydrated mucus cord (MC). DF, descending filaments.

(g) Higher magnification of the dorsal arch, showing dense ciliation 

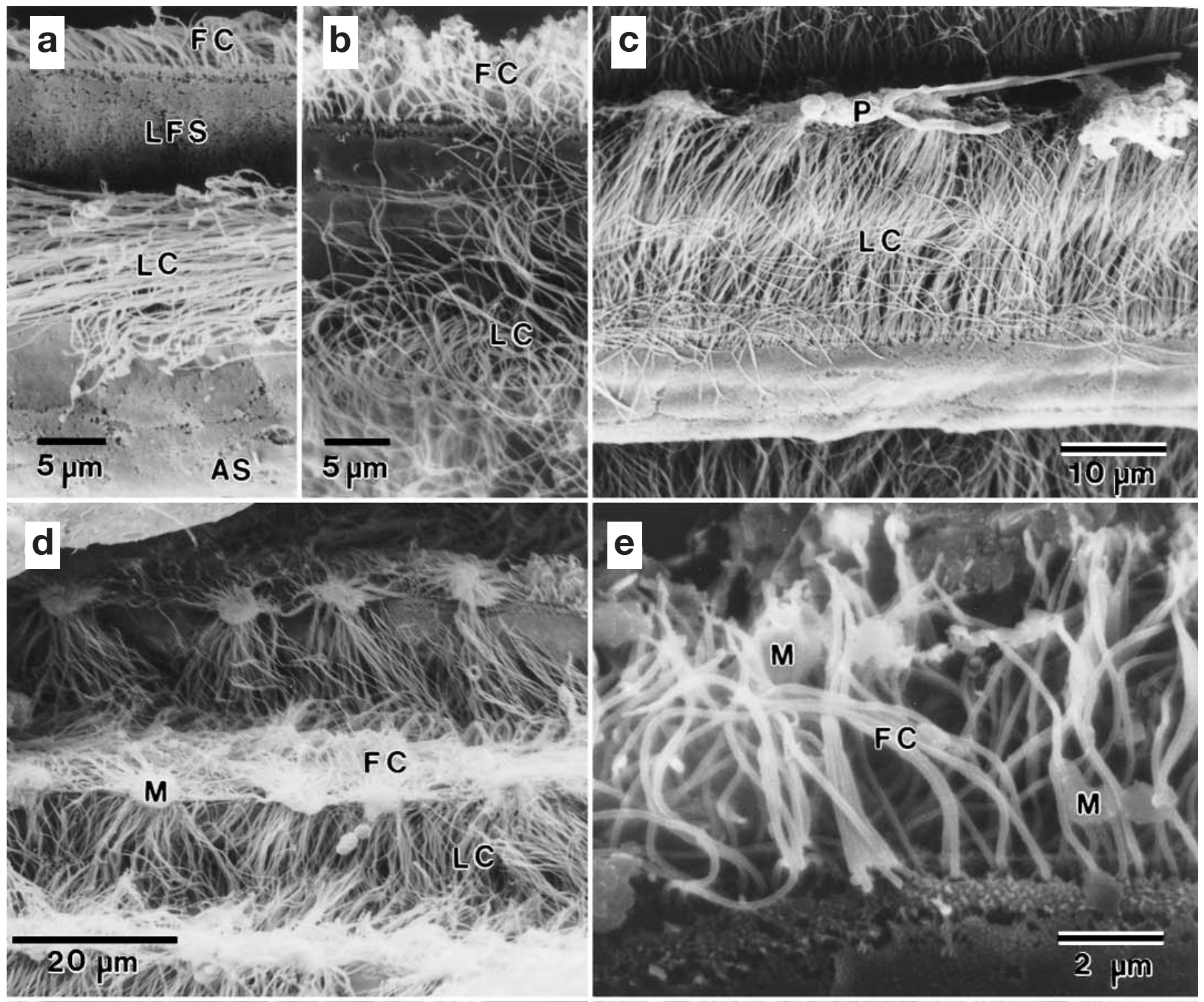

\section{FC}
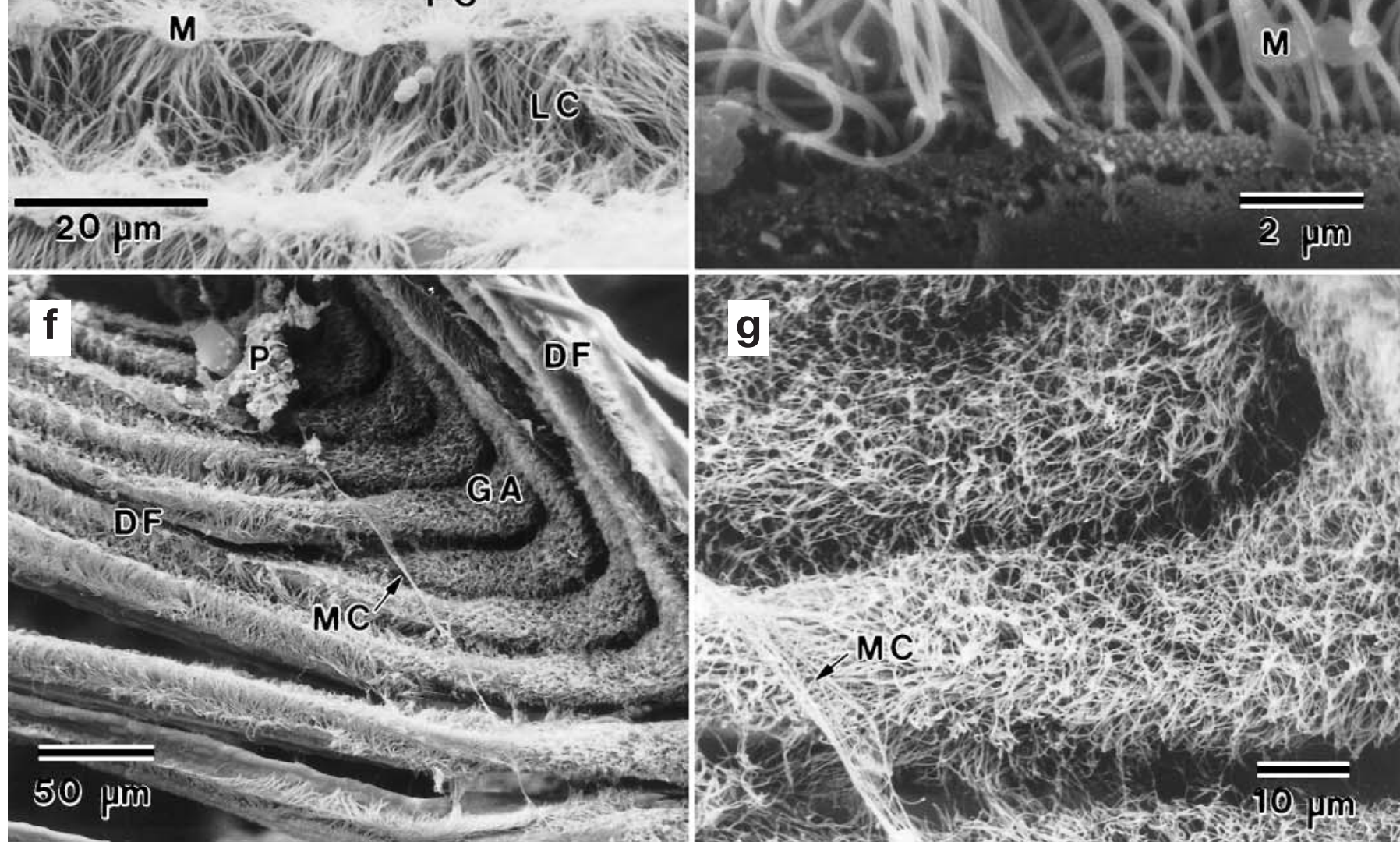


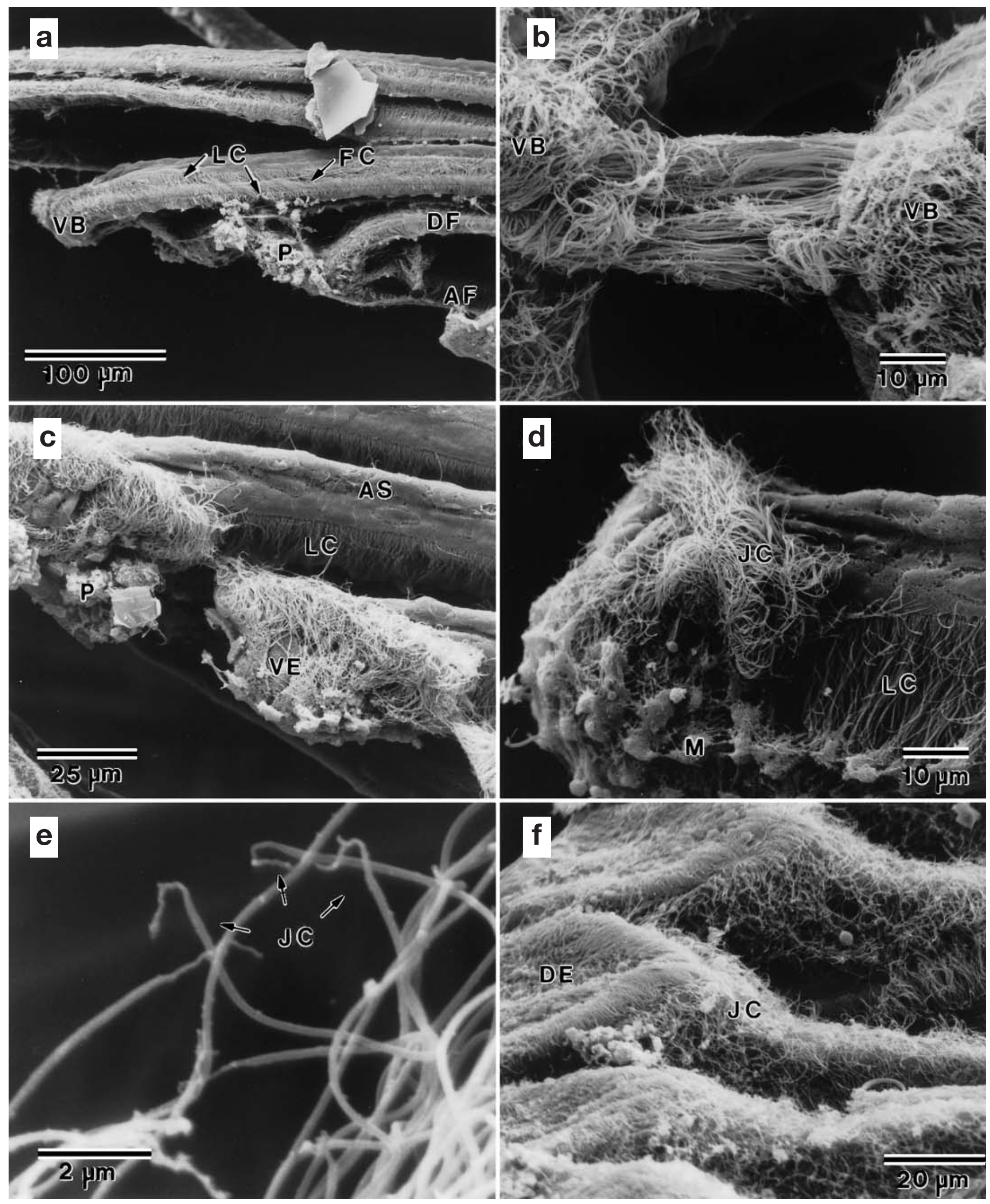


Fig. 4. Bathypecten vulcani. Scanning electron micrographs of gill filaments. (a) View of the ventral bend (VB), between descending filaments (DF) and ascending filaments (AF) of the inner dembranch. FC, frontal cilia; LC, lateral cilia; $\mathrm{P}$, mucus-particle masses. (b) Ciliary junction between individual filaments, at the ventral bend. (c) Abfrontal view of the ventral extremity (VE) of the descending filaments of the outer demibranch. AS, abfrontal surface. (d) Lateral view of the ventral extremity of a descending filament of the outer demibranch. Dehydrated mucus balls (M), probably the vestiges of a mucus raft, are seen along the frontal surface. JC, junctional or J-cilia. (e) Distal tip of a few J-cilia at the ventral extremities of descending filaments of the outer demibranch. (f) Frontal view of the dorsal extremities (DE) of the ascending filaments of the inner demibranch

\section{Mucocyte distribution}

After the gills were stained with PAS-AB, 2 mucocyte types were identified: those secreting acid mucopolysaccharides, stained in blue, and those secreting acid-dominant mucopolysaccharides, stained in purple (Table 1). Although both mucocyte types were located at the frontal surface of the filaments (Fig. 5a), the shape and position of the 2 differed: AM were spherical and situated at the frontal crest of the filaments, whereas ADM were curved ellipsoids, situated deeper within the filaments, at a latero-frontal position (Fig. 5b,f). The mean volume of the 2 mucocyte types also differed, averaging $1173 \mu^{3}$ for AM and $450 \mu^{3}$ for ADM.

Throughout the gill, ADM were more abundant than AM by an average factor of 14.5:1. In the whole mounts, the highest densities of mucocytes were found in the ventral bend (Fig. 5c) and the ventral extremities of the outer descending filaments (Fig. 5d). In these areas, mucocytes overlapped extensively, precluding mucocyte counts. No mucocytes were seen at the extremities of the ascending inner filaments (Fig. 5e).

Fig. 6 shows the distribution of both mucocyte types, as an average number and as a total mucocyte volume per $100 \mu \mathrm{m}$ of filament length, in each counting zone. Along the antero-posterior axis, the general trend of the AM and ADM mucocyte densities decreased toward the posterior zones. The non-parametric ANOVAs revealed significant differences in mucocyte densities along both the dorso-ventral and anteroposterior axes (Fig. 6). Highly significant ( $p \leq 0.001$ ) differences in mucocyte densities were found for ADM along the antero-posterior axis, and for AM along the dorso-ventral axis; significant differences ( $p \leq 0.05$ ) were also found for ADM along the dorso-ventral axis. The multiple comparisons tests revealed that densities of ADM were significantly higher in the anterior zones than in the posterior zones; they were also significantly higher in the dorsal zones than in the median zones (it should be noted, however, that at the extreme ventral gill extremities, ADM mucocytes were too dense to count individually). In addition, the AM densities were sig- nificantly higher in the dorsal zones than in either the median or ventral zones. There were no significant differences in AM densities along the antero-posterior axis.

The total mucocyte volumes give an estimate of the potential quantity and quality of mucus secreted in the different gill areas. The most acidic mucus (highest AM:ADM ratio) is secreted dorsally and anteriorly, whereas the least acidic mucus (lowest AM:ADM ratio) is secreted ventrally.

\section{DISCUSSION}

Some of the present observations confirm those of Le Pennec et al. (1988): both studies showed that the gill of Bathypecten vulcani is homorhabdic and has only frontal and lateral cilia, but no ventral groove or inter-lamellar fusion. However, the present data contrasts with that of Le Pennec et al. (1988) as follows: the present study reports an $\mathrm{N}$-shaped rather than a W-shaped gill, and shows the mucocytes to be abundant throughout the gill instead of only at the dorsal and ventral extremities. In addition, 2 types of mucocytes are documented, with differing distributions.

\section{Particle processing in Bathypecten vulcani}

\section{Gill currents}

Due to the ciliary junction of the extremities of the filaments with either the mantle (outer demibranch) or the other gill (inner demibranch), the mantle cavity can be separated into infra-branchial and supra-branchial chambers. Assuming that the lateral cilia behave as they do in other bivalves, and that the integrity of the

Table 1. Bathypecten vulcani. Pantone ${ }^{\mathrm{TM}}$ standard colors, visual colors, and corresponding mucocyte secretion types of gill mucocytes

\begin{tabular}{|lcc|}
\hline Pantone ${ }^{\mathrm{TM}}$ standard colors & Visual colors & Mucocyte secretion \\
\hline $2685 \mathrm{C}, 2726 \mathrm{c}$ & Purple & Acid-dominant mucopolysaccharide \\
299c, 300c, 3005c & Blue & Acid mucopolysaccharide \\
\hline
\end{tabular}




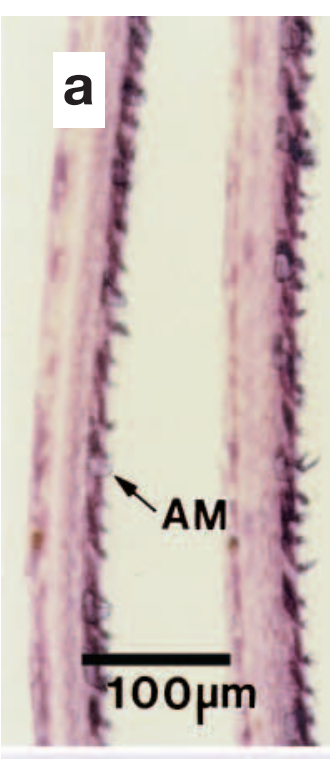

C

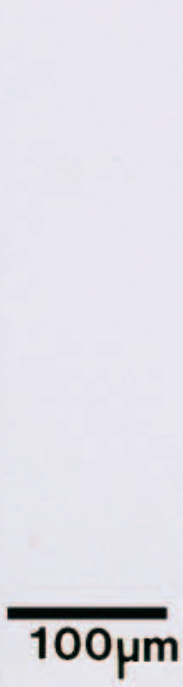

e
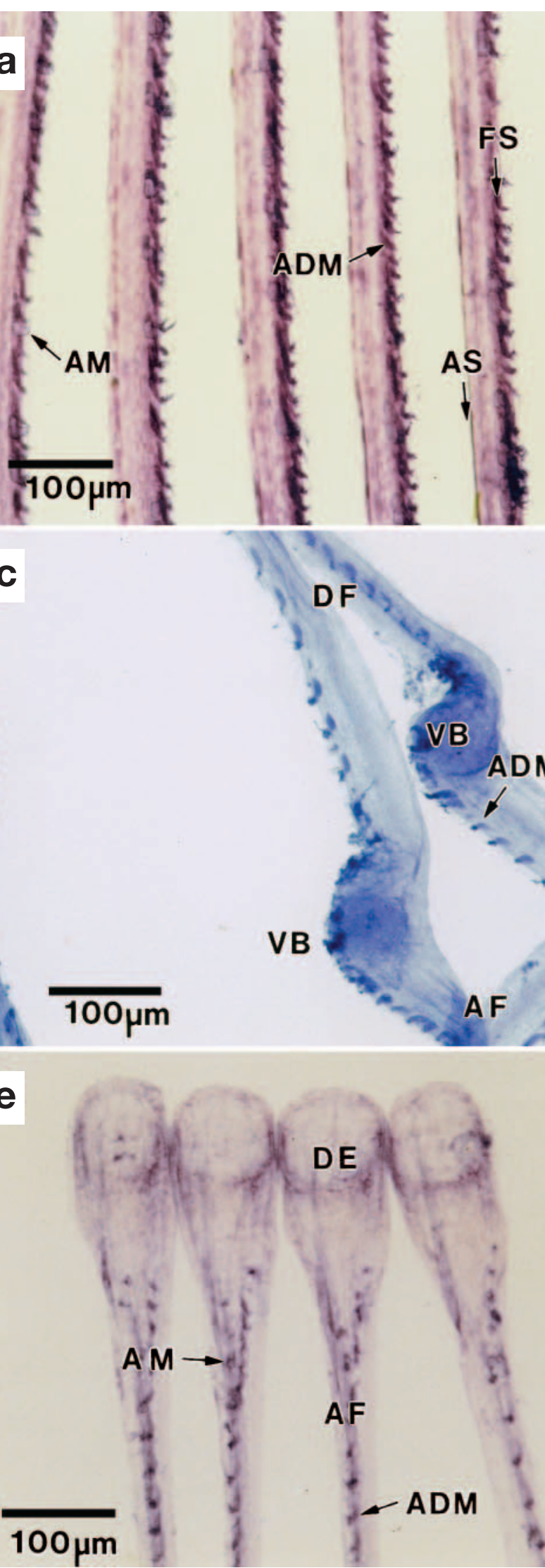

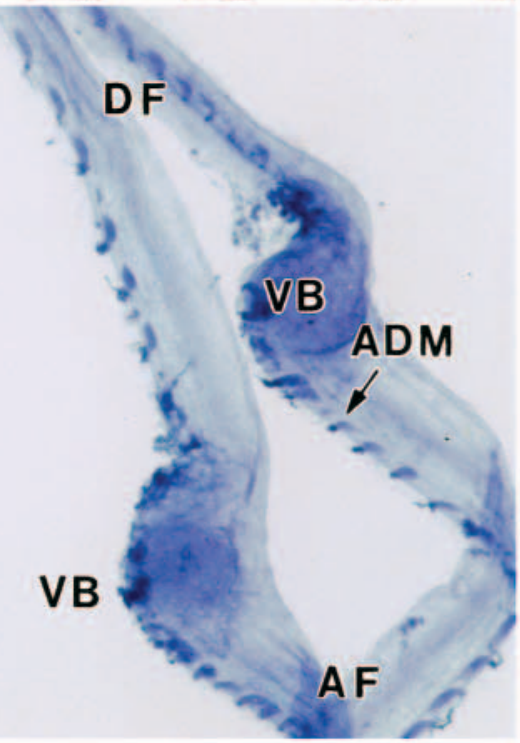

d
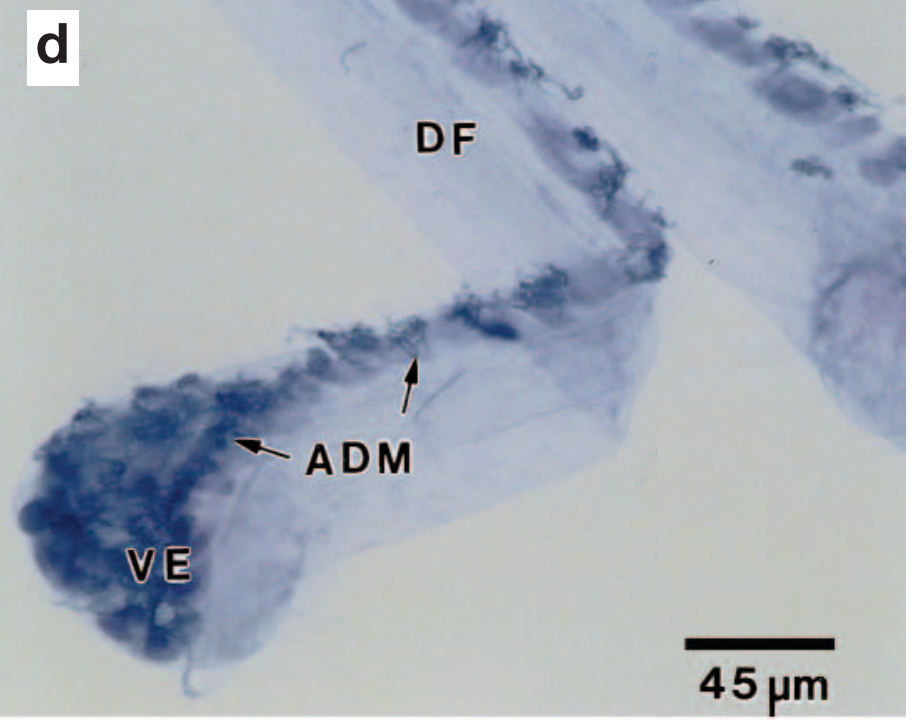

f

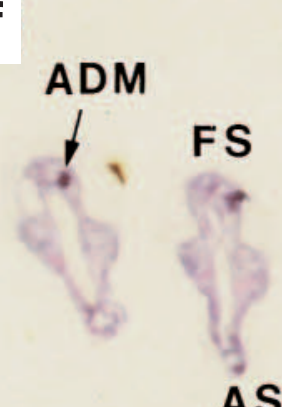

AS

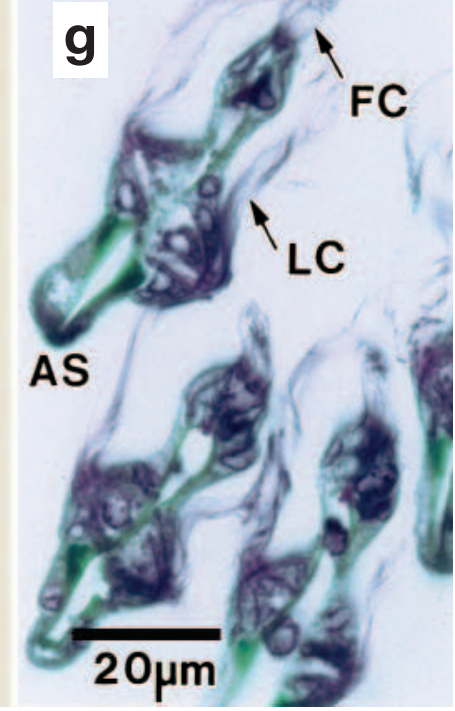


Fig. 5. Bathypecten vulcani. Whole-mount and transverse sections of gills stained with periodic acid-Schiff-Alcian Blue (PAS-AB; a-f) or Masson's trichrome (g). (a) Lateral view of whole-mount gill filaments, with acid mucocytes (AM) and acid-dominant mucocytes (ADM) at the frontal surface (FS) of the filaments. Note that most mucocytes were actively secreting at the time of fixation. AS, abfrontal surface. (b) Frontal view of whole-mount gill filaments near the gill arch (GA). (c) Lateral view of wholemount gill filaments showing the ventral bend (VB) between descending filaments (DF) and ascending filaments (AF) of the inner demibranch. (d) Lateral view of whole-mount gill filaments, revealing the ventral extremity (VE) of a descending filament of the outer demibranch. Note extremely dense concentrations of mucocytes at the ventral extremity frontal surface. (e) Frontal view of whole-mount gill filaments. The dorsal extremity (DE) of ascending filaments of the inner demibranch are visible. (f) Transverse sections of gill filaments. The acid-dominant mucocytes are in a latero-frontal position. $(\mathrm{g})$ Transverse sections of gill filaments. FC, frontal cilia; LC, lateral cilia

gill structure is not compromised by the lack of interfilamentary junctions, the lateral cilia create a flow of water from the infra-branchial to the supra-branchial chambers. This is consistent with gill through-currents in other autobranch bivalves (Atkins 1938a, Aiello \& Sleigh 1972, Jørgensen 1990).

\section{Particle capture}

The morphological and histochemical data of the present study suggest that suspended particles entrained by the frontal-abfrontal water flow are transported along the frontal mucociliary tracts in Bathy-

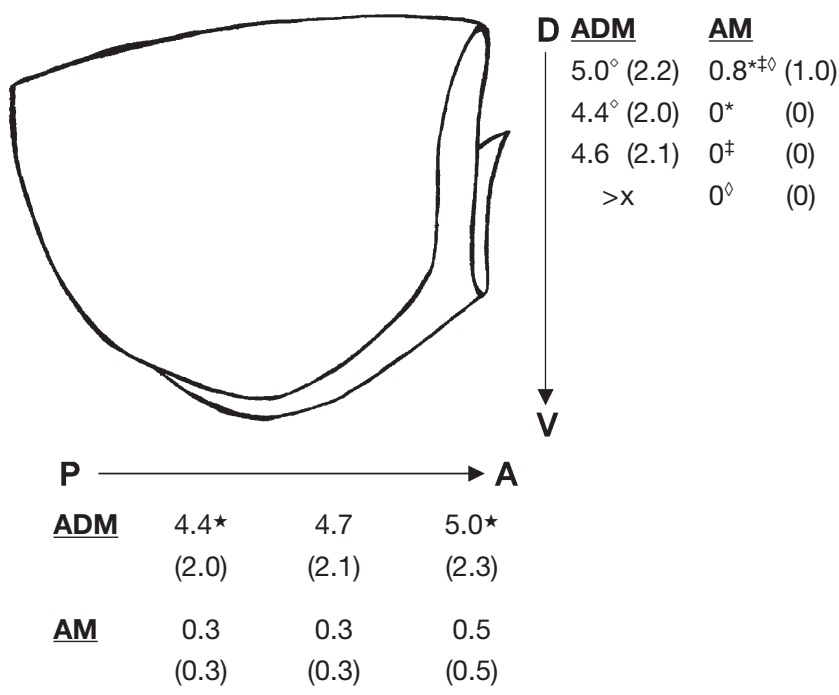

Fig. 6. Bathypecten vulcani. Mean mucocyte densities (per $100 \mu \mathrm{m}$ filament length) and, in parentheses, mean total mucocyte volumes $\left(\times 10^{3} \mu^{3}\right.$, per $100 \mu \mathrm{m}$ filament length $)$ along the dorso-ventral axis and the antero-posterior axis of the gill (right gill, viewed from the right side, is illustrated). Paired symbols in superscript indicate significant differences in mucocyte density between zones $(p \leq 0.05)$. In the ventralmost extremity of the filaments, the density of acid-dominant mucocytes was too high to allow counts to be made. A, anterior; $\mathrm{ADM}$, acid-dominant mucocytes; $\mathrm{AM}$, acid mucocytes; $\mathrm{D}$, dorsal; $\mathrm{P}$, posterior; $\mathrm{V}$, ventral pecten vulcani (Fig. 3c). Latero-frontal cilia are a consistent feature of bivalve gills, presenting various degrees of development (see Dufour \& Beninger 2001 for schematic diagram). In all autobranchs examined to date which possess homorhabdic gills, particle interception occurs through direct or hydrodynamically coupled contact with the latero-frontal cirri, diverting the particle's path to the frontal ciliary tract, where it becomes caught in the ventralward flow of water and mucus (Silverman et al. 1996, 1999). In bivalves having simple latero-frontal cilia, such as the Pectinidae, the mechanism of particle capture is not yet clear. The gills of B. vulcani, however, have no latero-frontal cilia at all; the particles must simply come in contact with the frontal mucus rafts and become trapped in them. This would constitute a novel particle capture mechanism in the adult Bivalvia. It is possible that the lack of latero-frontal cilia in $B$. vulcani is representative of a primitive state, in which frontal cilia eventually differentiate and give rise to latero-frontal cilia and cirri. This scenario had been proposed as an explanation for the origin of latero-frontal cilia by Atkins (1938b), who did not know of any bivalve gills lacking latero-frontal cilia, but realized that there is much variability in the degree of differentiation of latero-frontal cilia from frontal cilia. The gill of $B$. vulcani may now provide evidence for the existence of this state in latero-frontal cilia evolution.

\section{Particle transport on the gill}

Once particles are captured on the gill, they are most likely incorporated into mucus cords on the frontal surface of the filaments. The dominance of $\mathrm{AM}$ and $\mathrm{ADM}$ follows the rule established for particle transport on an exposed surface (Beninger \& St-Jean 1997a), although the direction of transport with respect to current flow is not yet certain. Two possibilities for initial transport are theoretically possible: dorsalward and ventralward (there is no possibility for bi-directional transport or selection because the gills are homorhabdic and lack frontal tract dif- 
ferentiation). On the scanning electron micrographs, mucus and particles were seen in the dorsal arch, on the ventral bend, and on the ventral extremities of the outer demibranch (Figs. 3f,g \& 4a,c); although it is not possible to ascertain whether these positions are representative of those in live animals, the consistency of the positions both within and between individuals strongly suggests that these are natural. In all homorhabdic bivalves studied to date, initial transport on the gill is ventralward; however, such systems present a ventral particle groove which ensures that the anteriorly moving particle-mucus cords are not dislodged by the pallial water currents. Bathypecten vulcani lacks such a groove. Mucociliary transport in a grooveless ventral bend occurs in the heterorhabdic gill of Placopecten magellanicus, but in this species it is the particles destined for rejection that are directed to the ventral bend, where they travel for some distance anteriorly but eventually become dislodged and fall on the mantle prior to rejection (Beninger et al. 1999). The dorsal arch thus appears to be a more likely location for mucociliary transport than the ventral bend, given that the dorsal arch forms a semi-enclosed tract (as in Beninger et al. 1992 for $P$. magellanicus). The most convincing argument in favor of dorsalward transport on the gill is the presence of well-defined vestiges of dehydrated mucus cords in this region (Fig. 3f,g). Such cords, extending along the antero-posterior axis, demonstrate the existence of a transport function in the gill arch. Since bidirectional transport on this type of gill is not possible, dorsalward transport is thus the most probable initial trajectory for particles trapped on the frontal surface. The large numbers of particles trapped in mucus on the ventral gill extremities could indicate the principal site of initial particle capture, as explained below.

The distribution of mucocyte types on the gills of Bathypecten vulcani is not as homogenous as in other homorhabdic gills (Beninger et al. 1993, Beninger \& Dufour 1996): densities of AM and ADM were found to vary significantly between gill sites. In the absence of direct observations of particle processing in this species, it is not possible to relate these differences to observed aspects of processing. However, the viscosity of the secreted mucus is likely to be similar throughout the gill, due to the numerical dominance of ADM, and the functional similarities of acidic and acid-dominant mucus (Beninger \& St-Jean 1997a). The significantly larger amount of highly viscous MPS-secreting mucocytes (AM and ADM) in the anterior region and in the dorsal zones would be consistent with the use of an exposed mucus bridge for transfer between the gill and the labial palps, as has been shown in several bivalve particle-processing systems (Ward et al. 1993,
Beninger \& St-Jean 1997b, Beninger et al. 1997). Assuming the $B$. vulcani gill creates similar far-field currents to those of the Pectinidae, with water entry all around the ventral pallial margin, the very high density of mucocytes in the ventralmost gill extremities coincides with the site of initial encounter with particle-laden water currents from the external environment. This configuration supports the hypothesis of direct particle capture in frontal mucus rafts.

\section{Comparison with other pectinacean gills}

Although it may have been convenient, based on shell characters alone, to resolve the position of the genus Bathypecten, as well as the relationship between propeamussid and pectinid forms by creating 2 subfamilies within the Pectinidae (Schein 1989), the result places a homorhabdic (propeamussids) and a heterorhabdic (pectinids) group within the same family. The scale of the anatomical and functional differences between these 2 gill types argues against such an association, and in the present discussion, the term 'pectinid' is restricted to members of the pectinid, rather than the propeamussid, form.

The gill structure of Bathypecten vulcani is much simpler than all known pectinid gills, with the exception of Hemipecten forbesianus, which has a homorhabdic gill with no inter-lamellar junctions (Yonge 1981). The gills of B. vulcani are also very different from propeamussid gills; in early descriptions of gills by Ridewood (1903), 3 species of Propeamussium sensu lato (Waller 1972), Amussium dalli, A. meridionale and $A$. lucidum had ascending lamellae in both demibranchs, whereas B. vulcani has N-shaped gills such as those present in the non-pectinacean bivalve genus Lasea (Ridewood 1903) and in the Anomalodesmata (Morton 1980). The only other previous detailed description of gill structure in the Propeamussiidae is of Propeamussium lucidum (Morton \& Thurston 1989). In this species, the gill has been described as completely devoid of both latero-frontal cilia or cirri and of ascending lamellae; the 2 descending lamellae of each gill have fused ventrally, creating a gill system incapable of particle capture, and therefore the species is assumed to be carnivorous. The gill of B. vulcani possesses ascending filaments on the 2 inner demibranchs, and its frontal surfaces are free to trap particles, which were often observed under SEM. These inconsistencies call for a re-examination of propeamussid gills, in order to ascertain eventual homologies or adaptive specializations. In particular, the status of Hemipecten forbesianus should be clarified, as it is to date the only pectinid form with a homorhabdic gill. 
The length of the frontal cilia in Bathypecten vulcani $(6 \mu \mathrm{m})$ is similar to that reported for the contemporary pectinid Placopecten magellanicus (Beninger et al. 1988), and contrasts with the much longer frontal cilia of the mytilid Mytilus edulis (approximately $15 \mu \mathrm{m}$ above the microvillar surface; Silverman et al. 1999). The physiological significance of the different cilia types and lengths in bivalves is a recent field of investigation (e.g. Beninger \& Veniot 1999, Beninger et al. 1999, Beninger \& Dufour 2000, Dufour \& Beninger 2001), and it is likely that much may be learned of bivalve particle processing and the evolution of the pallial surfaces through further detailed study of the types and distributions of cilia.

The structure of the gill arch of Bathypecten vulcani can be compared with that of other known pectinacean gills. In B. vulcani, the filaments are well-defined and abundantly ciliated thoughout the gill arch (Fig. 3f,g); in Placopecten magellanicus, the filaments in the gill arch have the same aspect but are somewhat less abundantly ciliated (Beninger et al. 1988). The gill arch of Propeamussium lucidum (although seemingly not used in particle processing) appears to consist of a ciliated groove which is separate from the gill filaments (Morton \& Thurston 1989); this differs from the condition in B. vulcani.

The gills of Bathypecten vulcani show many similarities with early ontogenetic stages of pectinid gills. In Pecten maximus and Placopecten magellanicus, developing gills are first flat and homorhabdic, then flat and heterorhabdic, and finally plicate and heterorhabdic (Beninger et al. 1994, Veniot et al. in press). In early stages of $P$. maximus measuring up to $4 \mu \mathrm{m}$, the gill axis is straight, and there are no laterofrontal cilia (Beninger et al. 1994). Given such great similarity in gill structure, it may be assumed that the feeding mechanisms of these 2 species in different stages of development are similar. This is especially significant in light of the uncertainty of the evolutionary position of the relict pectinacean $B$. vulcani with respect to the contemporary Pectinidae, such as $P$. maximus. These similarities in gill structure between $B$. vulcani and the early ontogenetic stages of $P$. maximus support a phylogenetic link between B. vulcani and modern pectinids.

\section{CONCLUSIONS}

The present observations of the structure and ultrastructure of the gills of Bathypecten vulcani allow us to infer probable particle processing mechanisms on the gills of this species. It is clear that the gills cannot function as pectinid gills since they are not heterorhabdic. They cannot function as most homorhabdic gills either, due to their lack of a ventral groove and latero-frontal cilia. Following particle capture, dorsalward transport on the gill is the most probable initial transport path, to the gill arch and thence anteriorward to the labial palps. Particle capture is the most enigmatic aspect of feeding in $B$. vulcani: the most plausible mechanism is that particles are simply caught in the frontal mucus tracts, most probably at the ventral gill extremities, without prior ciliary interception. This primitive mode of feeding, reminiscent of that in postlarvae of Pecten maximus, is probably not very efficient in the capture of small particles (poor development of laterofrontal cilia is related to poor retention of small particles; Møhlenberg \& Riisgård 1979, Riisgård 1988). However, given the small size of the animal, the $B$. vulcani gill is extremely large, such that it offers a comparatively large surface for the capture of larger particles, often observed on the ventral extremities of the gill.

The small body size, large gill (with few filaments), and rarity of Bathypecten vulcani are typical features of deep-sea suspension-feeding bivalves without endosymbionts (Allen 1979, Oliver 1979). Although the distribution of $B$. vulcani appears to be limited to the fringes of hydrothermal vents, the trophic strategy of this species appears to be the processing of seston. Its reliance on the vent habitat may be related to the opportunity for byssal attachment, as well as to the relatively high concentrations of particulate matter in these environments (Enright et al. 1981, Gage \& Tyler 1991).

Bathypecten vulcani thus appears to be dependent on the hydrothermal vent system for habitat, but contrary to the other sympatric bivalve species, appears not to present an endosymbiont-based trophic strategy.

These observations constitute the first, albeit indirectly, substantiated representations of primitive autobranch particle processing, prior to the evolution of ventral grooves, latero-frontal cilia, or the heterorhabdic condition. This information may thus serve as a starting point for the understanding of the evolution of particle processing mechanisms in the diverse array of contemporary autobranch bivalves.

Acknowledgements. We thank F. Gaill for authorizing the study of Bathypecten vulcani specimens provided by P. Briand and M. Segonzac following the HOT 96 cruise, as well as $\mathrm{H}$. Felbeck for providing support and submarine time for the samplings in 2000. Funding during this research was provided by the Syndicat Mixte pour le Développement de l'Aquaculture et de la Pêche en Pays de la Loire, although not for this project. We are grateful to the City of Nantes for a travel scholarship to P.D. 


\section{LITERATURE CITED}

Aiello E, Sleigh MA (1972) The metachronal wave of lateral cilia of Mytilus edulis. J Cell Biol 54:493-506

Allen JA (1979) The adaptations and radiation of deep-sea bivalves. Sarsia 64:19-27

Atkins D (1938a) On the ciliary mechanisms and interrelationships of lamellibranchs. Part VI. Pattern of the lateral ciliated cells of gill filaments. Q J Microsc Sci 80: 330-344

Atkins D (1938b) On the ciliary mechanisms and interrelationships of lamellibranchs. Part VII. Latero-frontal cilia of the gill filaments and their phylogenetic value. Q J Microsc Sci 80:345-437

Beninger PG, Dufour SC (1996) Mucocyte distribution and relationship to particle transport on the pseudolamellibranch gill of Crassostrea virginica (Bivalvia: Ostreidae). Mar Ecol Prog Ser 137:133-138

Beninger PG, Dufour SC (2000) Evolutionary trajectories of a redundant feature: lessons from bivalve gill abfrontal cilia and mucocyte distributions. In: Harper EM, Taylor JD, Crame JA (eds) The evolutionary biology of the bivalvia. Geol Soc Lond Spec Publ 177:273-278

Beninger PG, Le Pennec M (1991) Functional anatomy of scallops. In: Shumway SE (ed) Scallops: biology, ecology and aquaculture. Elsevier, Amsterdam, p 133-224

Beninger PG, St-Jean SD (1997a) The role of mucus in particle processing by suspension-feeding marine bivalves: unifying principles. Mar Biol 129:389-397

Beninger PG, St-Jean SD (1997b) Particle processing on the labial palps of Mytilus edulis and Placopecten magellanicus (Mollusca: Bivalvia). Mar Ecol Prog Ser 147:117-127

Beninger PG, Veniot A (1999) The oyster proves the rule: mechanisms of pseudofeces transport and rejection on the mantle of Crassostrea virginica and C. gigas. Mar Ecol Prog Ser 190:179-188

Beninger PG, Le Pennec M, Salaün M (1988) New observations of the gills of Placopecten magellanicus (Mollusca: Bivalvia), and implications for nutrition. I. General anatomy and surface microanatomy. Mar Biol 98:61-70

Beninger PG, Ward JE, MacDonald BA, Thompson RJ (1992) Gill function and particle transport in Placopecten magellanicus (Mollusca: Bivalvia) as revealed using video endoscopy. Mar Biol 114:281-288

Beninger PG, St-Jean S, Poussart Y, Ward JE (1993) Gill function and mucocyte distribution in Placopecten magellanicus and Mytilus edulis (Mollusca: Bivalvia). Mar Ecol Prog Ser 98:275-282

Beninger PG, Dwiono SAP, Le Pennec M (1994) Early development of the gill and implications for feeding in Pecten maximus (Bivalvia: Pectinidae). Mar Biol 119:405-412

Beninger PG, Potter TM, St-Jean SD (1995a) Paddle cilia fixation artifacts in pallial organs of adult Mytilus edulis and Placopecten magellanicus (Mollusca: Bivalvia). Can J Zool 73:610-614

Beninger PG, Donval A, Le Pennec M (1995b) The osphradium in Placopecten magellanicus and Pecten maximus (Bivalvia: Pectinidae): histology, ultrastructure and implications for spawning synchronisation. Mar Biol 123: 121-129

Beninger PG, Dufour SC, Bourque J (1997) Particle processing mechanisms of the eulamellibranch bivalves Spisula solidissima and Mya arenaria. Mar Ecol Prog Ser 150: 157-169

Beninger PG, Veniot A, Poussart Y (1999) Principles of pseudofeces rejection on the bivalve mantle: integration in particle processing. Mar Ecol Prog Ser 178:259-269
Childress JJ, Felbeck H, Somero GN (1987) Symbiosis in the deep sea. Sci Am 256:114-120

Dufour SC, Beninger PG (2001) A functional interpretation of cilia and mucocyte distributions on the abfrontal surface of bivalve gills. Mar Biol 138:295-309

Enright JT, Newman WA, Hessler RR, McGowan JA (1981) Deep-ocean hydrothermal vent communities. Nature 289: 219-221

Gage JD, Tyler PA (1991) Deep-sea biology: a natural history of organisms at the deep-sea floor. Cambridge University Press, Cambridge

Jørgensen CB (1990) Bivalve filter-feeding: hydrodynamics, bioenergetics, physiology and ecology. Olsen \& Olsen, Fredensborg

Le Pennec M, Beninger PG (2000) Reproductive characteristics and strategies of reducing-system bivalves. Comp Biochem Physiol A 126:1-16

Le Pennec M, Herry A, Lutz R, Fiala-Médioni A (1988) Première observations ultrastructurales de la branchie d'un Bivalve Pectinidae hydrothermal profond. CR Acad Sci Paris 307:627-633

Le Pennec M, Beninger PG, Herry A (1995) Feeding and digestive adaptations of bivalve molluscs to sulphide-rich habitats. Comp Biochem Physiol A 111:183-189

Le Pennec G, Beninger PG, Le Pennec M, Donval A (in press) Aspects of the feeding biology of Bathypecten vulcani, a possibly relict peri-hydrothermal vent bivalve. J Mar Biol Assoc UK

Martoja R, Martoja M (1967) Initiation aux techniques de l'histologie animale. Masson et cie, Paris

Møhlenberg F, Riisgård HU (1979) Filtration rate, using a new indirect technique, in thirteen species of suspensionfeeding bivalves. Mar Biol 54:143-148

Morton B (1980) Anatomy of the 'living fossil' Pholadomya candida Sowerby 1823 (Bivalvia: Anomalodesmata: Pholadomyacea). Vidensk Medd Dan Nat Hist Foren 142:7-101

Morton B, Thurston MH (1989) The functional morphology of Propeamussium lucidum (Bivalvia: Pectinacea), a deepsea predatory scallop. J Zool 218:471-496

Oliver PG (1979) Adaptations of some deep-sea suspensionfeeding bivalves (Limopsis and Bathyarca). Sarsia 64: 33-36

Page HM, Fiala-Médioni A, Fisher CR, Childress JJ (1991) Experimental evidence for filter-feeding by the hydrothermal vent mussel, Bathymodiolus thermophilus. Deep-Sea Res 38:1455-1461

Ridewood WG (1903) On the structure of the gills of the Lamellibranchia. Phil Trans R Soc Lond B 195:147-284

Riisgård HU (1988) Efficiency of particle retention and filtration rate in six species of northeast American bivalves. Mar Ecol Prog Ser 45:217-223

Schein E (1989) Pectinidae (Mollusca, Bivalvia) bathyaux et abyssaux des campagnes BIOGAS (Golfe de Gascogne) Systématique et biogéographie. Ann Inst Oceanogr Paris 65:59-125

Schein-Fatton E (1985) Découverte sur la ride du Pacifique oriental à $13^{\circ} \mathrm{N}$ d'un Pectinidae (Bivalvia, Pteriomorphia) d'affinités paléozoïques. CR Acad Sci Paris Ser III 301: 491-496

Schein-Fatton E (1988) Un Pectinacea (Bivalvia) très primitif: Bathypecten vulcani, du site hydrothermal de $13^{\circ} \mathrm{N}$ (Pacifique oriental). Oceanol Acta (Spec Iss) 83-98

Shank TM, Fornari DJ, Von Damm KL, Lilley MD, Haymond RM, Lutz RA (1998) Temporal and spatial patterns of biological community development at nascent deep-sea hydrothermal vents ( $9^{\circ} 50^{\prime} \mathrm{N}$, East Pacific Rise). Deep-Sea Res II 45:465-515 
Silverman H, Lynn JW, Dietz TH (1996) Particle capture by the gills of Dreissena polymorpha: structure and function of latero-frontal cirri. Biol Bull 191:42-54

Silverman H, Lynn JW, Beninger PG, Dietz TH (1999) The role of latero-frontal cirri in particle capture by the gills of Mytilus edulis. Biol Bull 197:368-376

Tunnicliffe V (1991) The biology of hydrothermal vents: ecology and evolution. Oceanogr Mar Biol Annu Rev 29: 319-417

Van Dover CL (2000) The ecology of deep-sea hydrothermal vents. Princeton University Press, Princeton, NJ

Veniot A, Bricelj VM, Beninger PG (in press) Ontogenetic changes in gill morphology and potential significance for food acquisition in the scallop Placopecten magellanicus. Mar Biol

Editorial responsibility: Otto Kinne (Editor),

Oldendorf/Luhe, Germany
Waller TR (1972) The functional significance of some shell microstructures in the Pectinacea (Mollusca: Bivalvia). Proc Int Geol Cong, 24th session, Montreal, Canada. Section 7, Paleontology, p 48-56

Ward JE, Beninger PG, MacDonald BA, Thompson RJ (1991) Direct observations of feeding structures and mechanisms in bivalve molluscs using endoscopic examination and video image analysis. Mar Biol 111:287-291

Ward JE, MacDonald BA, Thompson RJ, Beninger PG (1993) Mechanisms of suspension-feeding in bivalves: resolution of current controversies by means of endoscopy. Limnol Oceanogr 38:265-272

Yonge CM (1981) On adaptive radiation in the Pectinacea with a description of Hemipecten forbesianus. Malacologia 21:23-34

Submitted: January 16, 2002; Accepted: October 15, 2002 Proofs received from author(s): January 6, 2003 